\title{
Mediation in Juvenile Criminal Offenses - Albanian Case
}

\section{Jola Bode}

Assoc. Prof. Dr, Faculty of Law, University of Tirana

\section{Abstract}

In the treatment of juvenile ofenders in modern systems, priority is being given to procedures aimed at reconciliation and mediation, damage repair and the implementation of alternative measures to restrict freedom. The entirety of such proceedings fall within the concept of restorative justice. Restorative justice is of particular importance in the treatment of juveniles by the criminal justice system, as its main purpose is not to punish the perpetrator but to find methods that promote reintegration into society. One of the mechanisms that underpins restorative justice for juveniles that guarantees the success of education and reintegration in society is mediation in criminal conflicts. The mediation aims to engage the perpetrator in repairing the damage caused by the criminal offense as well as to restore reconciliation relations between the victim and the perpetrator. In this way, mediation procedures are of particular importance in the context of criminal law as they promote the values of dialogue and reconciliation in the way of conflict resolution and provide alternative solutions to criminal sanctions. In criminal cases involving juvenile offenders, the application of mediation procedures brings a number of positive aspects as it serves the immediate rehabilitation and reintegration of the juvenile offender as the primary aim of juvenile justice. Implementation of the mediation alternative leads to a better understanding of legislation in this area as well as an increased awareness of enabling application as one of the forms of intervention against juvenile delinquency. Restorative justice is already part of the juvenile criminal legislation following the entry into force of the Juvenile Criminal Code, which brings a new perspective to the implementation of restorative procedures in accordance with the principle of protecting the best interest of the minor. The paper focuses on the role and importance of mediation procedures and their sanctioning in Albanian legislation. The paper will analyze albanian mediation legislation as a positive achievement in the context of promoting the process of restorative justice in juvenile matters. Conclusions will be drawn and recommendations will be identified regarding deficiencies in legal regulations as well as the practical implementation of mediation procedures for juveniles.

Keywords: Juvenile Criminal Code, restorative justice, mediation, juvenile offender, prosecution avoidance 


\section{Introduction}

In cases of juvenile offenders, criminal punishment should be the last resort leaving space for other solutions where restorative justice also plays an important role. Restorative justice reflects a humane and democratic attitude in dealing with crime, in a way that benefits victims, offenders, the community and society at large, conceptualizing it as a win-win process for all involved actors ${ }^{1}$. Restorative justice requires the active participation of the victim and the perpetrator, as opposed to the criminal procedure where the judge makes the decision. It is oriented towards repair compensation, rather than punishment ${ }^{2}$.

Mediation is an important aspect of restorative justice. Mediation is based on an agreement between the offender and the injured party and ensures the settlement of the conflict through reconciliation, thereby avoiding litigation. In this way, juvenile offenders are provided with more effective opportunities to remedy the consequences of the action taken and to integrate into the community and to restore violated rights to the victim by repairing the damage caused by the offense.

Researchers define it as: "a confidential, law-abiding litigation where the parties voluntarily participate, aimed at resolving disputes arising from the commission of a criminal offense, using the services of an independent and impartial third party"3.

$t$ is thought that the mediation process as an element of restorative justice was developed around the 70's, first in the US and Canada and then in the European countries 4 . Nowadays mediation is taking on particular importance in matters involving minors. The application of mediation procedures allows juveniles to avoid criminal proceedings such as the application of criminal sanctions in accordance with the requirements of international standards.

At the same time, mediation procedures and contact with the victim raise the juvenile's awareness of the consequences of his or her actions and future failure to serve as a basic element of education. Mediation also serves to restore the rights of the victim as the victim receives proper sodisfaction through forms such as penance or compensation for the damage caused.

In this way, the application of mediation for juvenile offenders, in contrast to criminal sanctions, is also of interest to society as the primary interest of society is the education of juveniles and the avoidance of any possibility of continuing criminal

\footnotetext{
1 Foundation "Conflict Resolution and Dispute Settlement", (2007), Summary of Conference Proceedings, "Implementing Restorative Justice and Mediation in the European Perspective", Tirana 2324 May, p. 12.

2 Save the Children, (2015), Handbook, Mediation Service and Restorative Justice for Juveniles in Conflict with the Law, Tirana , p. 14.

${ }^{3}$ Conflict Resolution and Dispute Settlement Foundation, (2007), Restorative Justice and Mediation in Criminal Dispute Resolution, Handbook for Judges and Prosecutors, UNICEF, Tirana, p. 6.

${ }^{4}$ Gjoka. R, (2007), Restorative justice and mediation in criminal matters, published by the Foundation for Conflict Resolution and Dispute Settlement, West Print, Tirana, p. 11.
} 
activity. The practice of serving sentences for juveniles within the existing infrastructure, in the absence of specialized institutions, has already shown that serving the sentence has not served their education properly. In some cases the period spent in penitentiary institutions has had negative effects in terms of returning to criminal activity. Likewise, the restoration of the relationship between the offender and the victim serves the well-being and possibility of peaceful co-existence of all community members. To this end, priority should be given to the mediation process as a means of resolving criminal conflicts for juveniles, thus avoiding the negative effects of facing criminal proceedings.

\section{The historical context}

Resolution of mediation disputes has existed as one of the forms of conflict resolution even in the Albanian historical context. Initially mediation procedures were regulated by customary law rules. The canons envisaged detailed rules regarding reconciliation procedures, ceremonies, or even reconciliation symbols that varied from province to province ${ }^{1}$. In Albanian customary law, canonical norms have been used mainly in reconciliation of blood feuds in order to limit blood feuds and hostilities. During the period of Skanderbeg's state and the Ottoman occupation a great development took the institute of covenants that served the process of reconciliation ${ }^{2}$. During the fascist occupation, the basis for settling disputes served acts issued by organisms created during the anti-fascist national-liberation war.

After the liberation of the country, the role of mediator was played by blood reconciliation committees and then by social courts as well as village, city and neighborhood courts ${ }^{3}$. These courts were empowered to make conciliation efforts in criminal matters pursued at the injured party's request. Procedures for resolving the case with reconciliation were also provided for by the criminal procedural legislation. Reconciliation could lead to the prosecution not being initiated or dismissed, at the stage of investigation or trial, as a consequence of the waiver of the accusative victim's appeal5. The courts also had the right to dismiss criminal cases

\footnotetext{
1 In the Canon of Lek Dukagjini one of the symbols of reconciliation and forgiveness of blood was the brooding provided in its paragraph 989-990. Another symbol was that of the blood of bread, namely the lunch after reconciliation, and of the cross at the door as a sign of forgiven blood, as provided in paragraph 983.

2 Elezi. I, (2005), Mediation for Reconciliation in Criminal Conflicts, published by the Dispute Resolution Conflict Reconciliation Foundation, pp. 32-34.

3 Elezi. I, (2005), Tradition and practice in applying conciliation mediation in the criminal field, reference given at the National Conference on Mediation, published by the Foundation "Conflict Resolution and Dispute Settlement", Tirana 27-28 April, p. 34.

${ }^{4}$ Criminal Procedural Code of 1979 Art. 125.

${ }^{5}$ According to Article 98/2 of the Criminal Procedure Code of 1953 as well as Article $71 / 5$ of the 1979 Criminal Procedure Code, one of the reasons for the failure to institute criminal proceedings was the case where the injured party withdrew his claim.
} 
that were not pursued by the injured party's appeal in cases where the guilty pleaded guilty and the educational purpose of the sentence was fulfilled ${ }^{1}$.

In 1990 by law no. 7383, dated 08.05.1990, the social courts were established which had the object of their activity as well as the settlement of disputes between the citizens for the criminal offenses prosecuted at the request of the injured party. Researchers think that these courts took on the character of social organisms that underlie the idea of reconciliation ${ }^{2}$.

With the adoption of the Criminal Code (CC) and the Code of Criminal Procedure (CPC), the institute of mediation was not explicitly provided for in the criminal and procedural legislation of the Republic of Albania. However, Article 48 of the CC adopted by law no. 7895 , dated 27.01 .1995 provides for mitigating circumstances as well as aspects related to the reconciliation and restoration of relations between the offender and the victim or his family, such as:

a) the person shows deep repentance;

b) replaces the damage caused by the criminal offense or actively helps to eliminate or reduce its consequences;

c) the relationship between the perpetrator and the victim is normalized.

\section{Albanian legislation on mediation}

Mediation procedures have found expression in Albanian legislation, initially with the adoption of Law no. 8465, dated 11.03.1999 "On mediation for the settlement of disputes" and subsequently with Law no. 9090, dated 26.06.2003 "On mediation in the settlement of disputes" which repealed the former. and further by Law no. 10385, dated 24.02.2011 "On mediation in the settlement of disputes" which is currently in force. The adoption of this legislation is of great importance as it institutionalizes mediation as an alternative to the resolution of criminal cases by creating real opportunities for its implementation in juvenile matters.

The law contains procedural principles and rules on the basis of which mediation will take place, outlining the rules related to the procedure of its development and the conditions for appointing a mediator. The law does not provide for special procedures for the development of juvenile mediation, but there is no impediment to existing procedures also being applied to mediation of juvenile offenders.

\footnotetext{
1 This competence was provided for in Article 73/1 of the 1979 Criminal Procedure Code which provided that:

"The court, the single judge or the investigator shall, in exceptional cases, have the right not to commence a criminal case, or during the investigation and trial in the first instance to dismiss it, when they consider that the danger of the offense committed and of the person is minor. and when he shows deep repentance. In these cases, the non-initiation or termination of the criminal case may also be initiated at the request of the state authorities, social organizations and labor associations. "

2Elezi. I, (2005), Mediation for Reconciliation in Criminal Conflicts, published by the Foundation "Conflict Resolution and Dispute Settlement", Tirana,pg 2.
} 
In this law, mediation is defined as "extrajudicial activity, in which the parties seek the settlement of a dispute by a neutral third party (mediator), in order to reach an acceptable settlement of the dispute and which is not contrary to the law. "1.

A very important aspect of this law is the provision of mediation also for criminal conflicts for a category of criminal offenses with low social risk ${ }^{2}$. The category of offenses for which mediation may be applied are those provided for in Articles 59 and 284 of the CPC. More specifically, mediation in the criminal field applies in the following cases:

Cases that are examined by the court at the request of the accusing injured party pursuant to Article 59 CPC.

In these cases the injured accuses has the right to file a claim with the court and to attend the trial as a party to prove the charge and to claim damages. Instead of litigation, the court may propose that the parties resolve the conflict through mediation. In the context of Article 59 of the CPC, mediation may apply to this category of offenses:

Other intentional injuries (Article 90), gross negligent injury (Article 91), minor negligent injury (Article 92), house rape (Article 112, first paragraph), insult (Article 119), insult motives of racism or xenophobia through a computer system (Article 119 / b), defamation (Article 120), unfair interference with privacy (Article 121), disclosure of personal secrets (Article 122), non-providing livelihoods (Article 125), unfair treatment of the child (Article 127), and violation of the inviolability of the home (Article 254).

All the offenses set forth in Article 284 CCP for which the prosecution can be initiated by the prosecution only with the appeal of the injured party who may withdraw it at any stage of the proceedings.

Prosecution authorities, the judicial police and the prosecution can play a positive role in this regard, which in such cases can inform the injured party of his right to settle the case through mediation. Referring to Article 284 of the CCP these cases relate to criminal offenses such as:

Intimidation (Article 84), light intentional injury (Article 89), sexual intercourse with increased violence (Article102), sexual or homosexual abuse (Article 105), sexual or homosexual intercourse with family members or custodian (Article 106), coercion or obstruction of cohabitation or dissolution of marriage (Article 130), publication of another's work under his own name (Article 148), unlawful reproduction of another's work (Article 149), assault on members the family of the person performing a state duty (Article 243), violation of the right of residence (Article 254), obligation to

\footnotetext{
${ }^{1}$ Law no. 10385, dated 24.02.2011 "On mediation in the settlement of disputes", Article 1.

2 Idem, article 3.
} 
participate or not to strike (Article 264), malicious use of telephone calls (Article 275), violation of traffic rules (Article 210 / first paragraph) and insult of a judge (Article 318).

The law marks an important step towards alternative resolution of criminal disputes as it enables the offenses provided for in Articles 59 and 284 of the CCP to be resolved extrajudicially. The novelty of the new law relates to the obligation of the court in the case of disputes in the criminal field as above to invite the parties to resort to mediation procedure for their settlement ${ }^{1}$. This rule is in line with the provisions of Article 338 of the CPC which establishes the same obligation of the court to propose to the parties to settle the case concurrently in the case of offenses prosecuted at the request of the injured party.

Now, for the offenses provided for in Articles 59 and 284 committed by juveniles, the parties must first be subject to mediation and only if it fails should refer the matter to the justice authorities. The law in question is very detailed with regard to the principles on which the mediation will be based, the procedure for its development and the appointment of experts and the legal significance of the mediation agreement. Among the most important principles enshrined in the law are the volontary participation, the preservation of confidentiality and the respect for the equality of parties in the mediation procedure ${ }^{2}$. The law also sanctions the right to participate in the mediation procedure. It guarantees the parties the right to nominate a mediator or mediators as well as to determine the rules and procedure of mediation. This important principle enshrined in Article 3 of the law serves the effectiveness of the development of the mediation procedure as well as the positive consequences that are finalized in its agreement.

A guarantee of the success of the proceedings is the legal value of the agreement reached by the parties as well as the consequences of this agreement if the parties do not object. Resolution of the case through mediation and acceptance of the agreement by the parties leads to the non initiation of criminal proceedings or termination of the criminal case ${ }^{3}$. In criminal cases where juveniles are involved, if the case is resolved through mediation, the prosecutor or judge decides to dismiss the case $\mathrm{e}^{4}$.

Such an aspect is also sanctioned in the CPC which provides for the court or prosecutor's office to refrain from instituting criminal proceedings or ordering the dismissal of a criminal case if the matter has been settled through mediation. According to Article 290 / c of the CPC, one of the circumstances which does not allow the initiation of proceedings is also when the injured party's appeal is absent or when he withdraws the appeal.

\footnotetext{
1 Idem, article 2/5.

2 Idem, article 3.

3 Idem ,article $23 / 2$.

4 Idem, article 23/2/1.
} 


\section{Mediation in the Juvenile Justice Code}

Although mediation legislation has been in force since 1999, the concept of restorative justice was sanctioned by the entry into force of Law 37/2017 "Juvenile Justice Code" (Code). Restorative justice is mentioned in the Code, originally in Article 44 , which provides for the obligation of the competent authority to inform a minor in conflict with the law, victim, legal or procedural representative of restorative justice programs.

With the provision in the Code, restorative justice is now an integral part of the juvenile criminal justice system in accordance with the best interests of the juvenile. The manner of sanctioning is such that it considers not only the treatment of juveniles in conflict with the law, but also considers the interests of juvenile victims through their involvement in conflict resolution and the consequences of the offense.

Further, aspects related to restorative justice and mediation programs are regulated in the Code in Articles 63 and 64 where they are considered as alternative measures of avoidance of prosecution The importance of these programs relates to the fact that their successful implementation excludes juveniles in conflict with the law from formal investigation and adjudication procedures. This adjustment is in line with Council of Europe recommendations that promote out-of-court conflict resolution and international standards ${ }^{1}$.

Restorative justice and mediation programs can be implemented at any time, from the time a juvenile is detained, to the pre-trial investigation as well as the trial, provided that no final court decision is made. Although initiated on the proposal of the prosecutor or the judge, they take place outside the premises of the prosecution or court in accordance with an approach of frendly juvenile justice.

A restorative justice or mediation program can be applied to a juvenile ofender if two conditions are met:

- The minor, defense counsel and / or legal representative must freely give free consent to such a decision;

- Any agreement to remedy the consequences of the offense committed by the minor is reasonable or appropriate 2 .

The foregoing concludes that restorative justice procedures are voluntary procedures, meaning that they can be implemented only after the consent of the minor, his or her defense counsel or legal representative. The appearance of a free valve is a necessary condition for the whole process to operate, excluding any pressure, coercion or willful violation. The expression "must be reasonable" means that "if making this mediation decision or any other restorative justice program better

\footnotetext{
1 See Recommendation no. (81) 7 of the Council of Europe "On measures to facilitate access to justice", Recommendation no. (99) 19 "On mediation in criminal matters" etc.

${ }^{2}$ Code, Article 63/2 / (a) and 63/2 / (b).
} 
protects the parties, takes care of preserving the juvenile's dignity, prevents his or her physical, mental and emotional harm, then the court or prosecution has the right to decide it" 1 . The term also implies a decision making in accordance with the needs and the principle of the best interest of the minor.

The Code states that the implementation of a restorative justice program may be conditioned by the application of certain obligations to a minor in conflict with the law such as ${ }^{2}$ :

he or she understands the responsibility for the offense and its consequences; compensate for the harm caused to the victim, the community and / or society; apologize to the victim; and take action acceptable to the victim and / or the community.

Acknowledgment of responsibility for the offense is also closely linked to awareness of the consequences of the offense and the willingness to settle it. This means pleading guilty, taking responsibility and willingness to compensate for the damage caused. Apologizing is also part of the process of taking responsibility for the offense and correcting the consequences. Apologizing has a positive impact on the moral distress of the victims and has a positive impact on the successful development of mediation procedures.

Minors may also be required to apologize to the victim and to take other actions acceptable to the victim and / or the community. The nature of the actions required is not specified in the Code as it depends on the type of program to be implemented.

The types of restorative justice programs that the Code provides may include participation in a program of avoidance and mediation, work in the public interest, and / or any other program that leads to the rehabilitation of the consequences of an offense committed by a minor. ${ }^{3}$

The decision to implement the restorative justice program, as well as the case for mediation, is a matter for the prosecution body. At the investigative stage, the competent body is the prosecutor, while at the judicial stage is the judge of the case.

Concerning the procedures of mediation development, the Code refers to the special law on mediation. Beyond the provisions of the special law, Article 64 of the Code lays down certain specific conditions that refer to the mediation process with juvenile subjects as:

\footnotetext{
${ }^{1}$ School of Magistrates, (2019), Electronic Commentary, p. 127, (http://komentarielektronik.magjistratura.edu.al/), consulted March 16, 2019.

${ }^{2}$ Code, Article 63/4.

3 Idem, article 63/5.
} 
Mediation can only take place if there is free consent of the parties to the mediator, the accused juvenile and the injured party.

Mediation can only take place with the personal participation of the above parties.

We think that in the circle of persons whose presence is mandatory the psychologist and legal representative of the minor should also be included. This is also due to the fact that in juvenile justice procedures involving a minor in conflict with the law the participation of a psychologist and at the request of a minor is also mandatory for a trusted person ${ }^{1}$. The same principle has been sanctioned by international legal acts ${ }^{2}$.

The Code has specified some specific aspects of the juvenile mediation procedure. such as family mediation or group mediation. In this form of mediation, in addition to the juveniles in conflict with the law, the victim and the mediator participate on a case-by-case basis as well as family and relatives, representatives of public agencies in the protection of children's rights. The purpose of family and group mediation is to prevent the escalation of future conflict in order to avoid retaliation by the victim's family members against the accused or his relatives ${ }^{3}$.

The competent bodies, the prosecutor or judge to assess whether mediation is the most appropriate alternative, consider such elements as: the nature of the offense, the circumstances in which the offense was committed, the juvenile's history, the likelihood of a return to normal relations between juveniles and the injured party, the possibility of reducing the harm of the injured party, the possibility of rehabilitation of the minor and its reintegration into society ${ }^{4}$. If the parties agree to the mediation procedure, this procedure is most in accordance with the rules and law of mediation, where the parties together with the mediator are the main actors.

In principle, the participation of the Prosecutor and the judge is not mandatory. furthermore, these proceedings take place outside the Prosecution and Court. The Code provides for the possibility that the Prosecutor may participate in this process if he or she so evaluates 5 . This implies that the participation of the Prosecutor in the process does not depend on the consent of the parties but on the assessment of the Prosecutor himself. In the legal literature, this element is regarded as the premise for a fruitful exchange and a constructive outcome. ${ }^{6}$

\footnotetext{
1 The Code of Criminal Procedure provides for the presence of a psychologist in the entirety of procedural actions committed against minors, such as the recognition of persons (Article 171/3), the questioning of a minor witness (Article 361 / a, paragraph 2) etc.

2 Council of Europe Recommendation (99) 19 "On mediation in criminal matters" concerning mediation in criminal matters requires that minors be entitled to parental assistance. The same document states that in cases of mediation with minors, all special rules that govern participation in court proceedings should be applied.

${ }^{3}$ School of Magistrates, Electronic Commentary.cited, pg. 125.

4 Code, Article 64/6.

5 Idem, Article 64/4.

${ }^{6}$ School of Magistrates, Electronic Commentary, cited, pg.125.
} 
In accordance with international standards ${ }^{1}$, mediation can be applied as a measure of prosecution avoidance, ie as a measure that excludes the juvenile from criminal proceedings, thus serving its rapid social reintegration. Implementation as a measure of prosecution avoidance implies that successfully terminating within the legal term of the mediation agreement results in the termination of criminal proceedings against a minor in conflict with the law. or judgment of the case ${ }^{2}$.

Mediation procedures can also be implemented as an opportunity to improve the relationship between the juvenile offender and the victim of the offense.

\section{Conclusions and recommendations}

Albania has made efforts to align legislation with international acts that place importance on restorative justice and mediation in criminal matters. The adoption of mediation legislation is a positive achievement in the context of promoting the restorative justice process. and avoiding the negative effects of a criminal process on juvenile offenders.

The first step in this direction was the adoption of the special law on mediation and, further, the adoption of the Juvenile Criminal Justice Code, where the notion of restorative justice was first sanctioned. The Code provides for a number of special arrangements for juvenile mediation procedures. Through this legal basis already restorative justice and mediation programs serve as alternatives to evading prosecution.

This enables the exclusion of juveniles from criminal proceedings as one of the principles deriving from international standards of juvenile criminal justice. Anticipating restorative justice and mediation programs in the Juvenile Criminal Justice Code is the right step in providing the necessary opportunities for juvenile offender rehabilitation, but also respecting the rights of juvenile victims.

However, both regarding the current legal regulation and the practical implementation of mediation procedures for juveniles it is worth highlighting some issues and addressing some of the following recommendations:

Mediation legislation, despite positive changes, has not yet provided adequate space for mediating cases with juvenile subjects.

Although mediation has been legally sanctioned since 1999, mediation procedures have not been properly used in resolving criminal disputes involving juveniles.

\footnotetext{
${ }^{1}$ Recommendation no. 87 (20) of the Committee of Ministers "Concerning the social response to juvenile delinquency", recommends to the Member States encouraging the development of mediation procedures at the prosecutor's or police level in order to prevent juveniles from entering the criminal justice system and suffering from the consequences arising therefrom .

2The Code has set a deadline of 45 days as the maximum deadline for conducting a mediation procedure. See, Code, article 64/7.
} 
The current law on mediation does not provide for detailed regulations on the development of the mediation procedure for juveniles, referring to Juvenile Criminal Code.

The Code does not provide details about programs that can be pursued in the context of restorative justice and mediation, and Albanian case law is still limited in this regard.

Mediation programs still have a limited scope only for the category of offenses prosecuted at the request of the accusing injured party or for which prosecution begins with the injured party's complaint.

The above mentioned legal framework for mediation needs further improvements which will increase the degree of its implementation and compliance with the requirements of international legal acts. To increase the degree of enforceability, the mediation process should not be limited to the cases provided for by law, but may also extend to other offenses of low social risk. Legal amendments should allow for the addition of criminal offenses for which mediation for juveniles can be conducted, including criminal offenses, or other offenses of minor importance other than those provided for in Articles 59 and 284 of the Code of Criminal Procedure.

An alternative may be the application of mediation as an alternative to prosecution for offenses punishable by up to 5 years of imprisonment or a fine. This would harmonize mediation legislation with the Code's provisions where avoidance measures apply to offenses with such penalty margins.

At the same time, harmonization of the Code with the law on mediation and the rest of the legislation, in particular the Code of Criminal Procedure, is necessary.

\section{Bibliography}

[1] Elezi. I, (2005), Mediation for Reconciliation in Criminal Conflicts, published by the Dispute Resolution Conflict Reconciliation Foundation, Tirana.

[2] Elezi. I, (2005), Tradition and practice in applying conciliation mediation in the criminal field, reference given at the National Conference on Mediation, published by the Foundation "Conflict Resolution and Dispute Settlement", Tirana 27-28 April.

[3] Foundation "Conflict Resolution and Dispute Settlement", (2007), Summary of Conference Proceedings, "Implementing Restorative Justice and Mediation in the European Perspective", Tirana 23-24 May.

[4] Conflict Resolution and Dispute Settlement Foundation, (2007), Restorative Justice and Mediation in Criminal Dispute Resolution, Handbook for Judges and Prosecutors, UNICEF, Tirana.

[5] Gjoka. R, (2007), Restorative justice and mediation in criminal matters, published by the Foundation for Conflict Resolution and Dispute Settlement, West Print, Tirana. 
[6] Save the Children, (2015), Handbook, Mediation Service and Restorative Justice for Juveniles in Conflict with the Law, Tirana.

[7] Constitution of the Republic of Albania (1998).Law no. 1650 dated, 30.03. 1953, "Criminal Procedural Code of the Popular Republicof Albania ".

[8] Law no. 6069 dated, 25.12. 1979, " Criminal Procedural Code of the Socialist Popular Republic of Albania ".

[9] Law no. 8465, dated 11.03.1999 "On mediation for the settlement of disputes" [10] Law no. 9090, dated 26.06.2003 "On mediation in the settlement of disputes"

[11] Law no. 10385, dated 24.02.2011 "On mediation in the settlement of disputes"

[12] Law no. 7895 dated, 27.01. 1995, "Criminal Code of the Republic of Albania", as amended.

[13] Law no. 7905 dated, 21.03. 1995, "Criminal Procedural Code", as amendet.

[14] Laë no. 37/2017 Juvenile Criminal Code.

[15] Recommendation no. 87 (20) of the Committee of Ministers "Concerning the social response to juvenile delinquency

[16] Recommendation no. (81) 7 of the Council of Europe "On measures to facilitate access to justice",

[17] Recommendation no. (99) 19 "On mediation in criminal matters" 